\title{
Revision-mediated and Attention-mediated Feedback: Effects on EFL Learners' Written Syntactic Accuracy
}

\author{
Fatemeh Soltanpour ${ }^{1 *}$, Mohammadreza Valizadeh ${ }^{2}$ \\ ${ }^{1}$ English Department, Kar Higher Education Institute, PO box 1571, Qazvin, Iran \\ ${ }^{2}$ English Department, Faculty of Foreign Languages, Gazi University, PO Box 06500, Ankara, Turkey
}

Corresponding Author: Fatemeh Soltanpour, E-mail: fatemeh.soltanpour@gmail.com

\section{ARTICLE INFO}

Article history

Received: March 19, 2018

Accepted: June 17, 2018

Published: August 31, 2018

Volume: 9 Issue: 4

Advance access: July 2018

Conflicts of interest: None

Funding: None

\section{Key words:}

Comprehensive direct corrective

feedback,

Revision,

Attention,

Noticing,

Argumentative essays

\begin{abstract}
Based on the literature, revision requirement (i.e., when students rewrite their whole text based on the teacher feedback) can perhaps be a necessary intermediate step towards the development of written accuracy because learners have more time to think about and process the corrections; however, some state drawing learner's attention can be achieved by asking them to take time to look over the received feedback and carefully examine their errors. This quantitative quasiexperimental study, which followed a pretest-treatment-posttest-delayed posttest design, investigated the effects of revision mediation versus attention mediation on EFL learners' syntactic accuracy of their argumentative essays. 83 Iranian EFL learners, studying at upperintermediate level were assigned to three groups: comprehensive direct corrective feedback plus a revision requirement $(\mathrm{DCF} /+\mathrm{R})$, comprehensive $\mathrm{DCF}$ plus a time to pay careful attention to and study the errors and received feedback $(\mathrm{DCF} / \mathrm{S})$ and the control group that received the comprehensive DCF without any extra assignment (DCF/-R,-S). Each group received three sessions of treatment. The existence of any statistically significant differences among the three groups with regard to each received treatment was investigated both in the short and long term. It was found that both revision requirement $(\mathrm{DCF} / \mathrm{R})$ and careful attention requirement $(\mathrm{DCF} / \mathrm{S})$ significantly outperformed the group that only received the feedback. Nevertheless, it was also proved that the group that was required to pay careful attention to and study the feedback $(\mathrm{DCF} /+\mathrm{S})$ significantly outperformed the one that experienced the revision requirement $(\mathrm{DCF} / \mathrm{R})$. Discussion focuses on the importance of two levels of awareness: noticing and understanding.
\end{abstract}

\section{INTRODUCTION}

Feedback is considered a crucial element in second language (henceforth, L2) writing courses (Ferris, 2014) due to the fact that it has not only the potential for the development of L2 writing skills, but it can also enhance the students' motivation (K. Hyland \& Hyland, 2006). Further, if learners are not required to respond to the received written corrective feedback (henceforth, WCF), they may ignore it or attend to it only partially (Ellis, 2009; Liu \& Brown, 2015). Therefore, it has been suggested that in order to engage the learners with the feedback and also hold them accountable for their learning, they be required to revise their essays based on the teacher's feedback (Ferris, 2006; Guénette, 2012; F. Hyland, 2003; Shintani \& Ellis, 2015; Storch \& Wigglesworth, 2010).

Some scholars believe that revision requirement can be a helpful and perhaps necessary intermediate step towards the long-term acquisition of a specific feature (Ferris, 2004, 2010; Guénette, 2012; Sachs \& Polio, 2007) and "a necessary first step in the development of written accuracy"
(Liu \& Brown, 2015, p. 67) because learners have more time to think about and process the corrections and try to fix the errors and modify their texts (Ferris, 2010). As Sachs and Polio (2007) argued, "reports of noticing during the processing of written feedback were related to subsequent revision changes" (p. 85). In addition, "during revision, learners are able to access their explicit L2 knowledge and notice the gap between it and their first draft production." (Williams, 2012, p. 324) Moreover, the absence of a feedback-revision cycle may convey a view among many learners "that they have nothing to learn from their written assignments" (K. Hyland, 2013, p. 184). Truscott and Hsu (2008) also believed that revision has an important role in good writing.

As a result, several researchers have included the revision in their studies and found positive results (e.g., Chandler, 2003; Frear, 2012; Mawlawi Diab, 2015; Shintani, Ellis, \& Suzuki, 2014; Suzuki, 2012; Van Beuningen, De Jong, \& Kuiken, 2012). Based on Shintani et al., (2014), the found effectiveness of revision requirement can be mostly explained 
according to Swain's (1985) 'pushed output' hypothesis, which states that WCF combined with the opportunity to revise results in pushed output, contributing to the noticing of grammatical forms that may otherwise be ignored. When learners are required to revise their texts, they need to pay attention to their initial errors and the correction, which can promote storage of the features in memory. Shintani and Ellis (2013) also stated that more intensive feedback in conjunction with the 'pushed output' which can be provided by revision "will facilitate the development of implicit knowledge over time." (p. 301)

On the other hand, some scholars stated that even under the condition of no revision opportunity, WCF can be effective (Shintani \& Ellis, 2015) and learners can succeed in noticing corrections (Ellis, 2009) as long as learners are required to notice and process the received corrections (Shintani \& Ellis, 2015). Some believed that the methodological choice of revision requirement is neither essential to trigger noticing nor in line with normal WCF practice given in real classrooms due to the fact that the learners are usually not required to revise their written text based on teacher feedback (Stefanou \& Révész, 2015). It is also argued that the students can copy the corrections onto their revised texts passively and without noticing their errors and the provided WCF; consequently, it is vital that teachers draw learner attention to the target of the provided WCF (Polio, 2012; Stefanou \& Révész, 2015). Drawing learner attention can be achieved by asking them to take time to look over the received feedback and carefully examine their errors (Ellis, 2009; Polio, 2012). As a result, some researchers adopted this methodology (e.g., Ellis, Sheen, Murakami, \& Takashima, 2008; Sheen, 2007; Shintani \& Ellis, 2015; Stefanou \& Révész, 2015) and also found promising results.

\section{Review of Literature}

To begin with, because "there is a certain amount of discrepancy in the literature on the meaning of revision" (Bruton, 2009), it should be noted that in the present study, revision means that the students rewrite their whole text based on the teacher corrective feedback (henceforth, CF). Next, to the best knowledge of the researchers of the current research, no study has been published which systematically investigated different approaches to revision. Among the approaches to revision, this study looked for the literature about the two techniques of just carefully studying the corrected text and rewriting the whole text, which are of relevance to the purpose of this study.

Chandler (2003) compared indirect CF both with and without the opportunity to revise and found that the accuracy of group that was required to correct their errors significantly improved from the first to the fifth piece of writing significantly, but no improvement in fluency was revealed. Chandler concluded that "what seems to be a crucial factor. is having the students do something with the error correction besides simply receiving it" (p. 293).

Shintani et al., (2014) explored the effects of two types of feedback (direct and metalinguistic explanation) under two conditions (with and without the opportunity to rewrite) on two English grammatical structures (the indefinite article and past hypothetical conditionals). Regarding the accurate use of the indefinite article, neither type of feedback had any effect in new pieces of writing under either condition. Nonetheless, both types of feedback resulted in improved accuracy in the past hypothetical conditional, and also the direct feedback in conjunction with revision proved the most effective type.

\section{The Significance and Question of the Current Research}

First, it is generally agreed that even if teachers provide the learners with sufficiently clear and useful feedback, learners also must work with it to improve their writing (Elwood \& Bode, 2014), so learner engagement plays a critical role in the CF mechanism due to the fact that it mediates teacher provision of CF and learning outcomes (Ellis, 2010). Considering this, written revision would most likely have beneficial effects when learners have more time to think carefully about and process the received feedback (Ellis, 2009; Ferris, 2010; Guénette, 2007). Moreover, in order to help teachers enhance their WCF, a more thorough understanding of learner engagement with WCF is needed (Han \& Hyland, 2015) and thus, revision studies not only are interesting but also provide important evidence helping teachers refine their practice (Ferris, 2010).

Further, as Ellis (2009) mentioned,

The question of whether to require students to simply attend to the corrections or to revise based on them raises an interesting theoretical issue. Is it the additional 'input' that the corrections afford or the 'output' that occurs when students revise that is important for learning? (p. 106)

To the best knowledge of the researchers of the current research, no study has been published which systematically explored different approaches to revision. Thus, as the following question indicates, this study has compared the two methodologies of whether to require students to attend to the feedback or to revise their text based on the received teacher feedback.

RQ. To what extent is comprehensive direct corrective feedback combined with either students' attention to and studying the feedback or revising their texts based on teacher feedback effective in improving learners' grammatical written accuracy, relative to each other and to feedback-only methodology in both the short and long run?

Thus, this study includes three groups. What is common among all of them is that they all received comprehensive direct corrective feedback (henceforth, comprehensive DCF); however, one of them was also required to revise the texts based on the received WCF $(\mathrm{DCF} / \mathrm{R})$; the other one had to study the received feedback carefully $(\mathrm{DCF} /+\mathrm{S})$; the third group only received the comprehensive DCF and was not required to either revise or study the texts carefully (DCF/-R,-S).

\section{Theoretical Background}

Based on Output Hypothesis (Swain, 1985, 1995) and Noticing Hypothesis (Schmidt, 1990, 1995, 2001), when learners 
attempt to produce language via say, writing, they are encouraged to notice L2 forms they do not know and need to learn; moreover, when they receive feedback, they notice the gap between how they express their intentions and how a more proficient writer, say, the teacher expresses the same ideas. Additionally, when learners are required to revise their essays after receiving feedback, they are pushed to produce challenging output, so their awareness of linguistic input and gaps is raised and thus their progress towards the target language is facilitated. Therefore, the present study is in line with mentioned hypothesis.

\section{METHOD}

\section{Research Design and Setting}

The study was carried out at three branches of an EFL learning institute in Iran in real classrooms "within the context of an instructional program, with ecologically valid writing tasks", which was recommended by Storch (2010, p. 42). The study was a pretest-treatment-posttest-delayed posttest as well as a comparison-group one. There were three independent variables called 'DCF/+R', 'DCF/+S and 'DCF/-R,-S as well as a dependent variable named syntactic written accuracy. Therefore, because the non-random convenience sampling (i.e. intact classes) was utilized, the study is quasi-experimental.

\section{Participants and Groupings}

The participants consisted of the students in nine classes taught by the teacher-researcher. They were native speakers of Persian and studying the $2^{\text {nd }}$ edition of the book Summit 2, by Saslow and Ascher (2012). From the outset, there were 98 students. They were given the Oxford Quick Placement Test (henceforth, QPT). The score of 88 students ranged from 41 to 47 ; the rest were outliers; thus, those 88 learners were selected as the participants. It should be noted that because the research was conducted in English as a Foreign Language (EFL) intact classes, the treatments were done for all the students, but for the purpose of the research, the pre-, post, and delayed-posttests' scores of the students who had the necessary criterion - passing the upper-intermediate level, based on Geranpayeh's (2003) guideline - were considered. The students of three classes received the comprehensive DCF plus a revision assignment (henceforth, DCF/+R); the next three classes were provided with comprehensive DCF plus a time to pay attention and study the received feedback carefully (henceforth, DCF/+S); the remaining three classes received only the comprehensive DCF and were not required to either revise their texts or study them carefully (henceforth, DCF/-R,-S). Five learners were absent for the posttest or delayed-posttest, so they were discarded, and totally, 83 students (55 females and 28 males), ranging from 19 to 34 years old, formed the participants.

\section{Instrumentation}

Four tests were used in each group: QPT, a pretest, a posttest, and a delayed-posttest of argumentative essay writing.
Further, in order to assess the syntactic accuracy, the formula: [total number of syntactic errors/total number of words] $\times 100$, which was also used by Chandler (2003) as well as Truscott and Hsu (2008) was utilized.

\section{Data Collection Procedure}

The research was carried out in General English classes; the whole course lasted for 20 sessions (totally ten weeks), and each session lasted for 1 hour and 45 minutes. The focus of the course was not merely writing, so the teacher-researcher had a schedule to do the study. Table 1 indicates the procedure in the treatment period.

Some points need to be mentioned: first, based on Bitchener (2008), the participants were not told when the delayed post-test would be administered in order to eliminate the possibility of any student studying their personal notes or reviewing the -feedback. The teacher-researcher did not want the students to be prepared for the test beforehand. In addition, in order to control the effects of the other factors as much as possible (Guénette, 2007; Lalande, 1982; Sheppard, 1992), the same teacher (i.e., the teacher-researcher) taught the three groups. Further, the writing topics were similar in three groups.

\section{Type of provided feedback}

The teacher-researcher only corrected the participants' grammatical errors. However, because in case the learners commit a range of grammatical errors, "a limited $\mathrm{CF}$ focus does not address the need to individualize feedback according to students' different strengths and weaknesses" (Ferris, 2010, p. 192), the provided feedback on grammatical errors was unfocused or comprehensive, which is also the most widely used type of feedback by teachers (Ferris, 2006; Guénette, 2012; Lee, 2004, 2008; Van Beuningen, 2010) and liked by the students in some previous studies (Lee, 2005; Leki, 1991; Oladejo, 1993). Therefore, the unfocused feedback is more ecologically valid than the focused one. In addition, as the participants in the present study were the upper-intermediate ones, the unfocused WCF could be useful for them (Bitchener \& Ferris, 2012).

Moreover, among the WCF strategies, direct corrective feedback (DCF) was selected because DCF consists of an indication of the error and provision of the corresponding correct L2 form (Ellis, 2009), so the learners are provided with sufficient information to resolve complex linguistic errors, such as the syntactic ones (Chandler, 2003). Therefore, despite the fact that the participants were at upper-intermediate English proficiency, DCF was selected, which, based on Shintani and Ellis (2013), is more likely to facilitate learning in case the learners' level of (meta)linguistic competence is not high. All in all, the researchers of the present study intended to ensure that it was possible for the participating learners to not only notice the WCF but also to further process the information they obtained from the WCF. 
Table 1. Treatment period procedure

\begin{tabular}{|c|c|}
\hline Treatment period & Procedure \\
\hline \multicolumn{2}{|l|}{ Week 1} \\
\hline Session 1 & QPT was administered. \\
\hline Session 2 & The pretest was administered (i.e., the students wrote the $1^{\text {st }}$ essay of argumentative type in 40 minutes.) \\
\hline \multicolumn{2}{|l|}{ Week 2} \\
\hline Session 1 & $\begin{array}{l}\text { The students received the feedback. The participants in DCF/+R group were required to revise (i.e., rewrite) } \\
\text { their essays on a separate sheet of paper according to the provided feedback in } 20 \text { minutes, like the allocated } \\
\text { time in Suzuki (2012) and Shintani et al., (2014). The learners in DCF/+S were also given } 20 \text { minutes and } \\
\text { required to look over their errors and pay careful attention to the received feedback. The DCF/+S group } \\
\text { could also note their errors in their error notebooks if they thought it would help them remember the points. } \\
\text { The participants in the DCF/-R,-S only received the feedback and they were required to neither rewrite their } \\
\text { texts nor study the provided feedback. }\end{array}$ \\
\hline Session 2 & The students wrote the $2^{\text {nd }}$ essay in class in 40 minutes. \\
\hline \multicolumn{2}{|l|}{ Weeks 3} \\
\hline Session 1 & The same procedure as Session 1 of Week 2 was applied. \\
\hline Session 2 & The students wrote the $3^{\text {rd }}$ essay in class in 40 minutes. \\
\hline \multicolumn{2}{|l|}{ Week 4} \\
\hline Session 1 & The same procedure as Session 1 of Weeks $2 \& 3$ was applied. \\
\hline Session 2 & The posttest was administered. \\
\hline Weeks 5 \& 6 & No work on essay writing was done. \\
\hline \multicolumn{2}{|l|}{ Week 7} \\
\hline Session 1 & Delayed-posttest was administered. \\
\hline
\end{tabular}

Table 2. Inter-rater reliability

\begin{tabular}{llc}
\hline Groups & Tests & Indices \\
\hline $\mathrm{DCF} /+\mathrm{R}$ & Pretest & 0.99 \\
& Posttest & 0.94 \\
& Delayed posttest & 0.94 \\
$\mathrm{DCF} /+\mathrm{S}$ & Pretest & 0.99 \\
& Posttest & 0.90 \\
& Delayed posttest & 0.89 \\
$\mathrm{DCF} /-\mathrm{R},-\mathrm{S}$ & Pretest & 0.99 \\
& Posttest & 0.98 \\
& Delayed posttest & 0.82 \\
\hline
\end{tabular}

\section{The scoring procedure}

To assess the syntactic accuracy, the formula: [total number of syntactic errors/total number of words] $\times 100$ was utilized (Chandler, 2003; Truscott \& Hsu, 2008). Also, in order to prevent the possibility of the researcher's bias and considering the rater reliability (Mackey \& Gass, 2005) both researchers of the present study evaluated each essay independently, and the final score was the average score of the two raters.

\section{ANALYSES AND RESULTS}

\section{Inter-rater Reliability}

To assess the inter-rater reliability of the tests in the study, Cronbach alpha coefficient was utilized. Table 2 shows the results.
Table 2 indicates acceptable reliability indices.

\section{The Normality Tests}

The assumption of normality was examined through both the graphic of histogram and the numerical way recommended by Larson-Hall (2010); skewness statistics, kurtosis statistics, the ratio of skewedness and kurtosis over their respective standard errors were utilized as the numerical methods of assessing the normality (Field, 2013; Larson-Hall, 2010; Pallant, 2013; Phakiti, 2010). Based on Field (2013), if the outcomes of the ratio of skewedness and kurtosis over their respective standard errors are within the ranges of $+/-1.96$, the data enjoy normal distribution. Besides, Phakiti (2010) stated that in studies of applied linguistics, "values of skewness and kurtosis statistics within $+/-1$ suggest that the data set is normally distributed" (p. 45). Consequently, the histograms and the numerical methods revealed that all the tests enjoyed normal distribution. That is why they were analyzed through the parametric tests.

\section{Ensuring the Homogeneity of the Groups}

First, a one-way between-groups analysis of variance (ANOVA) was conducted to explore whether the three groups were homogeneous with regard to their scores on QPT in order to prove that the three groups enjoyed the same level of general English proficiency prior to the administration of the treatments. Tables 3 and 4 show the results.

Table 3 indicates that the significance value (Sig.) for Levene's Test is greater than.05 ( $\mathrm{Sig} .=.99)$; therefore, 
the assumption of homogeneity of variance was not violated.

As Table 4 reveals, there was not a significant difference among the three groups: $\mathrm{F}(2,80)=.030, \mathrm{p}=.97\left(\eta^{2}=.000\right)$. In conclusion, the participants in three groups were homogeneous regarding their general English proficiency.

Then, another one-way ANOVA was conducted to explore whether the three groups were homogeneous with regard to their syntactic accuracy, as measured by the pretest. Tables 5 and 6 indicate the results.

Table 5 indicates that the significance value (Sig.) for Levene's Test is greater than.05 (Sig. =.53); therefore, the assumption of homogeneity of variance was not violated.

As Table 6 reveals, there was not a significant difference among the three groups: $\mathrm{F}(2,80)=.173, \mathrm{p}=.84\left(\eta^{2}=.000\right)$. In conclusion, the participants in three groups were homogeneous regarding their grammatical accuracy in pretests.

\section{Findings of the Research Questions}

A one-way ANOVA was conducted to explore the short-term differences among the three groups with regard to the effect of each provided treatment, as measured by the posttests. Tables 7 to 11 reveal the results.

Table 7 indicates that the significance value (Sig.) for Levene's Test was less than.05 (Sig. =.000), so the assumption of homogeneity of variance was violated; thus, Robust Tests of Equality of Means were consulted (Pallant, 2013).

According to Tables 8 and 9, there was a statistically significant difference among the three groups: $F(2,80)=$ $178.279, \mathrm{p}=.000$. The effect size, calculated by using eta

Table 3. Test of homogeneity of variances for QPT

\begin{tabular}{lccc}
\hline Levene statistic & df1 & df2 & Sig. \\
\hline 0.001 & 2 & 80 & 0.999 \\
\hline
\end{tabular}

Table 4. ANOVA for QPT

\begin{tabular}{lccccc}
\hline & $\begin{array}{c}\text { Sum of } \\
\text { squares }\end{array}$ & df & $\begin{array}{c}\text { Mean } \\
\text { square }\end{array}$ & F & Sig. \\
\hline Between groups & 0.190 & 2 & 0.095 & 0.030 & 0.970 \\
Within groups & 249.328 & 80 & 3.117 & & \\
Total & 249.518 & 82 & & & \\
\hline
\end{tabular}

Table 5. Test of homogeneity of variances for pretest

\begin{tabular}{lccc}
\hline Levene statistic & df1 & df2 & Sig. \\
\hline 0.636 & 2 & 80 & 0.532 \\
\hline
\end{tabular}

Table 6. ANOVA for pretest

\begin{tabular}{lccccc}
\hline & $\begin{array}{c}\text { Sum of } \\
\text { squares }\end{array}$ & df & $\begin{array}{c}\text { Mean } \\
\text { square }\end{array}$ & F & Sig. \\
\hline Between groups & 0.004 & 2 & 0.002 & 0.173 & 0.841 \\
Within groups & 1.037 & 80 & 0.013 & & \\
Total & 1.042 & 82 & & & \\
\hline
\end{tabular}

squared was.81 $\left(\eta^{2}=.816\right)$, which is a large effect size and indicates $81.6 \%$ of the variability is due to the independent variable (i.e. the specific treatment).

Further, to find out which group had the higher scores, this significant ANOVA was followed by with Tukey's HSD post-hoc tests (Pallant, 2013).

As Tables 10 and 11 show, the mean scores for the posttests were statistically significantly different between $\mathrm{DCF} /+\mathrm{S}(\mathrm{M}=10.65, \mathrm{SD}=.28)$ and $\mathrm{DCF} /-\mathrm{R},-\mathrm{S}(\mathrm{M}=11.71$, $\mathrm{SD}=.07)(\mathrm{p}$-value $=.000<.05), \mathrm{DCF} /+\mathrm{R}(\mathrm{M}=10.90$, $\mathrm{SD}=.22)$ and $\mathrm{DCF} /-\mathrm{R},-\mathrm{S}(\mathrm{p}$-value $=.000<.05)$, and also between $\mathrm{DCF} /+\mathrm{S}$ and $\mathrm{DCF} /+\mathrm{R}$ (p-value $=.000<.05$ ). It should be noted that as the formula [total number of syntactic errors/total number of words $] \times 100$ was utilized for scoring the syntactic accuracy of the essays, the fewer errors the essays included, the smaller value (mathematical quantity) they were given, so the lower values reveal the existence of fewer errors and better performance. As a result, based on the mean scores, it can be concluded that in the short run, both $\mathrm{DCF} /+\mathrm{S}$ and $\mathrm{DCF} /+\mathrm{R}$ outperformed the $\mathrm{DCF} /-\mathrm{R},-\mathrm{S}$. Moreover, the $\mathrm{DCF} /+\mathrm{S}$ outperformed the $\mathrm{DCF} /+\mathrm{R}$.

Then, another one-way ANOVA was conducted to explore the long-term differences among the three groups with regard to the effect of each provided treatment, as measured by the delayed-posttests. Tables 12 to 16 indicate the results.

Table 12 indicates that the significance value (Sig.) for Levene's Test was less than.05 (Sig. =.005), so the assumption of homogeneity of variance was violated; thus, Robust Tests of Equality of Means were consulted (Pallant, 2013).

According to Tables 13 and 14, there was a statistically significant difference among the three groups: $\mathrm{F}(2,80)=$ $379.883, \mathrm{p}=.000$. The effect size, calculated by using eta squared was.90 $\left(\eta^{2}=.904\right)$, which is a large effect size and indicates $90.4 \%$ of the variability is due to the independent variable (i.e. the specific treatment).

Table 7. Test of homogeneity of variances for posttest

\begin{tabular}{lccc}
\hline Levene statistic & df1 & df2 & Sig. \\
\hline 18.058 & 2 & 80 & 0.000 \\
\hline
\end{tabular}

Table 8. ANOVA for posttest

\begin{tabular}{lccccc}
\hline & $\begin{array}{c}\text { Sum of } \\
\text { squares }\end{array}$ & df & $\begin{array}{c}\text { Mean } \\
\text { square }\end{array}$ & F & Sig. \\
\hline $\begin{array}{l}\text { Between } \\
\text { groups }\end{array}$ & 16.736 & 2 & 8.368 & 178.279 & 0.000 \\
$\begin{array}{l}\text { Within } \\
\text { groups }\end{array}$ & 3.755 & 80 & 0.013 & & \\
Total & 20.491 & 82 & & & \\
\hline
\end{tabular}

Table 9. Robust tests of equality of means for posttest

\begin{tabular}{lcccc}
\hline & Statistic $^{\mathbf{a}}$ & df1 & df2 & Sig. \\
\hline Welch & 305.399 & 2 & 41.899 & 0.000 \\
Brown-Forsythe & 181.181 & 2 & 55.730 & 0.000 \\
\hline
\end{tabular}


Table 10. Tukey HSD: Multiple comparisons for posttest

\begin{tabular}{llccccc}
\hline (I) Treatment & (J) Treatment & Mean difference (I-J) & Standard error & Sig. & \multicolumn{2}{c}{ 95\% confidence interval } \\
\cline { 5 - 7 } & & & & & Lower bound & Upper bound \\
\hline$(\mathrm{DCF} /+\mathrm{R})$ & $(\mathrm{DCF} / \mathrm{S})$ & $0.25214^{*}$ & 0.05790 & 0.000 & 0.1139 & 0.3904 \\
& $(\mathrm{DCF} / \mathrm{R},-\mathrm{S})$ & $-0.80659^{*}$ & 0.05844 & 0.000 & -0.9461 & -0.6670 \\
$(\mathrm{DCF} /+\mathrm{S})$ & $(\mathrm{DCF} /+\mathrm{R})$ & $-0.25214^{*}$ & 0.05790 & 0.000 & -0.3904 & -0.1139 \\
& $(\mathrm{DCF} /-\mathrm{R},-\mathrm{S})$ & $-1.05873^{*}$ & 0.05844 & 0.000 & -1.1983 & -0.9192 \\
$(\mathrm{DCF} /-\mathrm{R},-\mathrm{S})$ & $(\mathrm{DCF} / \mathrm{R})$ & $0.80659^{*}$ & 0.05844 & 0.000 & 0.6670 & 0.9461 \\
& $(\mathrm{DCF} / \mathrm{S})$ & $1.05873^{*}$ & 0.05844 & 0.000 & 0.9192 & 1.1983 \\
\hline
\end{tabular}

*The mean difference is significant at the 0.05 level.

Table 11. Descriptives for posttest

\begin{tabular}{|c|c|c|c|c|c|c|c|c|}
\hline & \multirow[t]{2}{*}{$\mathbf{N}$} & \multirow[t]{2}{*}{ Mean } & \multirow[t]{2}{*}{ SD } & \multirow[t]{2}{*}{$\begin{array}{l}\text { Standard } \\
\text { error }\end{array}$} & \multicolumn{2}{|c|}{$\begin{array}{l}\text { 95\% confidence interval for } \\
\text { mean }\end{array}$} & \multirow[t]{2}{*}{ Minimum } & \multirow[t]{2}{*}{ Maximum } \\
\hline & & & & & Lower bound & Upper bound & & \\
\hline$(\mathrm{DCF} /+\mathrm{R})$ & 28 & 10.9079 & 0.22656 & 0.04282 & 10.8200 & 10.9957 & 10.48 & 11.28 \\
\hline$(\mathrm{DCF} /+\mathrm{S})$ & 28 & 10.6557 & 0.28656 & 0.05415 & 10.5446 & 10.7668 & 10.16 & 11.20 \\
\hline$(\mathrm{DCF} /-\mathrm{R},-\mathrm{S})$ & 27 & 11.7144 & 0.07648 & 0.01472 & 11.6842 & 11.7447 & 11.57 & 11.85 \\
\hline Total & 83 & 11.0852 & 0.49989 & 0.05487 & 10.9760 & 11.1943 & 10.16 & 11.85 \\
\hline
\end{tabular}

Table 12. Test of homogeneity of variances for delayed-posttest

\begin{tabular}{lccc}
\hline Levene statistic & df1 & df2 & Sig. \\
\hline 5.717 & 2 & 80 & 0.005 \\
\hline
\end{tabular}

Table 13. ANOVA for delayed-posttest

\begin{tabular}{lccccc}
\hline & $\begin{array}{c}\text { Sum of } \\
\text { squares }\end{array}$ & df & $\begin{array}{c}\text { Mean } \\
\text { square }\end{array}$ & F & Sig. \\
\hline $\begin{array}{l}\text { Between } \\
\text { groups }\end{array}$ & 23.427 & 2 & 11.713 & 379.883 & 0.000 \\
$\begin{array}{l}\text { Within } \\
\text { groups }\end{array}$ & 2.467 & 80 & 0.031 & & \\
Total & 25.894 & 82 & & & \\
\hline
\end{tabular}

Table 14. Robust tests of equality of means for delayed-posttest

\begin{tabular}{lcccc}
\hline & Statistic $^{\mathbf{a}}$ & df1 & df2 & Sig. \\
\hline Welch & 557.701 & 2 & 49.193 & 0.000 \\
Brown-Forsythe & 384.269 & 2 & 66.654 & 0.000 \\
\hline
\end{tabular}

Further, to find out which group had the higher scores, this significant ANOVA was followed by with Tukey's HSD post-hoc tests (Pallant, 2013).

As Tables 15 and 16 show, the mean scores for the delayed-posttests were statistically significantly different between $\mathrm{DCF} /+\mathrm{S}(\mathrm{M}=10.34, \mathrm{SD}=.18)$ and $\mathrm{DCF} /-\mathrm{R},-\mathrm{S}$ $(\mathrm{M}=11.63, \mathrm{SD}=.02)(\mathrm{p}$-value $=.000<.05), \mathrm{DCF} /+\mathrm{R}$ $(\mathrm{M}=10.81, \mathrm{SD}=.21)$ and $\mathrm{DCF} /-\mathrm{R},-\mathrm{S}(\mathrm{p}$-value $=.000<.05)$, and also between $\mathrm{DCF} /+\mathrm{S}$ and $\mathrm{DCF} /+\mathrm{R}$ ( $\mathrm{p}$-value $=.000$ $<.05)$. As a result, based on the mean scores, it can be con- cluded that in the long run, also, both $\mathrm{DCF} /+\mathrm{S}$ and $\mathrm{DCF} /+\mathrm{R}$ outperformed the DCF/-R,-S. In addition, the DCF/+S outperformed the $\mathrm{DCF} /+\mathrm{R}$.

\section{DISCUSSION AND CONCLUSION}

Part of the findings of the present study revealed that both revision requirement $(\mathrm{DCF} /+\mathrm{R})$ and careful attention requirement $(\mathrm{DCF} /+\mathrm{S})$ significantly contributed to the efficacy of the DCF. This finding confirms the argument that even if teachers provide the learners with sufficiently clear and useful feedback, learners need to be engaged with the WCF and work with it to improve their writing (Elwood \& Bode, 2014; Han \& Hyland, 2015) and the required work had better draw learner's attention to the target of the provided WCF (Polio, 2012; Stefanou \& Révész, 2015). Although careful analysis is needed, it can also be concluded that the participants in the feedback-only group in the current study (i.e., DCF/-R,-S) may have ignored the DCF or attended to it only partially because they were not required to respond to or work with it; this was already predicted by Ellis (2009) as well as Liu and Brown (2015).

That revision requirement indicated promising results support the argument that written revision can be a good technique to engage the learners with the WCF and hold them accountable for their learning (see, e.g. Ferris, 2006; Guénette, 2012; F. Hyland, 2003; Shintani \& Ellis, 2015; Storch \& Wigglesworth, 2010) especially because via revising the texts based on the provided feedback, learners have more time to think carefully about and process the received feedback (Ellis, 2009; Ferris, 2010; Guénette, 2007).

Nevertheless, this study proved that requiring the learners to pay careful attention to and study the provided feedback was even more effective than the revision requirement. This 
Table 15. Tukey's HSD: Multiple comparisons for delayed-posttest

\begin{tabular}{|c|c|c|c|c|c|c|}
\hline \multirow[t]{2}{*}{ (I) Treatment } & \multirow[t]{2}{*}{ (J) Treatment } & \multirow[t]{2}{*}{ Mean difference (I-J) } & \multirow{2}{*}{$\begin{array}{l}\text { Standard } \\
\text { error }\end{array}$} & \multirow[t]{2}{*}{ Sig. } & \multicolumn{2}{|c|}{$95 \%$ confidence interval } \\
\hline & & & & & Lower bound & Upper bound \\
\hline \multirow[t]{2}{*}{$(\mathrm{DCF} /+\mathrm{R})$} & $(\mathrm{DCF} /+\mathrm{S})$ & $0.46643 *$ & 0.04693 & 0.000 & 0.3544 & 0.5785 \\
\hline & $(\mathrm{DCF} /-\mathrm{R},-\mathrm{S})$ & $-0.82452 *$ & 0.04736 & 0.000 & -0.9376 & -0.7114 \\
\hline \multirow[t]{2}{*}{$(\mathrm{DCF} /+\mathrm{S})$} & $(\mathrm{DCF} /+\mathrm{R})$ & $-0.46643^{*}$ & 0.04693 & 0.000 & -0.5785 & -0.3544 \\
\hline & $(\mathrm{DCF} /-\mathrm{R},-\mathrm{S})$ & $-1.29095^{*}$ & 0.04736 & 0.000 & -1.4041 & -1.1778 \\
\hline \multirow[t]{2}{*}{$(\mathrm{DCF} / \mathrm{R},-\mathrm{S})$} & $(\mathrm{DCF} /+\mathrm{R})$ & $0.82452 *$ & 0.04736 & 0.000 & 0.7114 & 0.9376 \\
\hline & $(\mathrm{DCF} /+\mathrm{S})$ & $1.29095^{*}$ & 0.04736 & 0.000 & 1.1778 & 1.4041 \\
\hline
\end{tabular}

*. The mean difference is significant at the 0.05 level.

Table 16. Descriptives for delayed-posttest

\begin{tabular}{|c|c|c|c|c|c|c|c|c|}
\hline & \multirow[t]{2}{*}{$\mathbf{N}$} & \multirow[t]{2}{*}{ Mean } & \multirow[t]{2}{*}{ SD } & \multirow[t]{2}{*}{$\begin{array}{l}\text { Standard } \\
\text { error }\end{array}$} & \multicolumn{2}{|c|}{$\begin{array}{l}\text { 95\% confidence interval for } \\
\text { mean }\end{array}$} & \multirow[t]{2}{*}{ Minimum } & \multirow[t]{2}{*}{ Maximum } \\
\hline & & & & & Lower bound & Upper bound & & \\
\hline$(\mathrm{DCF} /+\mathrm{R})$ & 28 & 10.8121 & 0.21436 & 0.04051 & 10.7290 & 10.8953 & 10.46 & 11.20 \\
\hline$(\mathrm{DCF} /+\mathrm{S})$ & 28 & 10.3457 & 0.18504 & 0.03497 & 10.2740 & 10.4175 & 10.06 & 10.74 \\
\hline$(\mathrm{DCF} / \mathrm{R},-\mathrm{S})$ & 27 & 11.6367 & 0.10770 & 0.02073 & 11.5941 & 11.6793 & 11.46 & 11.83 \\
\hline Total & 83 & 10.9230 & 0.56194 & 0.06168 & 10.8003 & 11.0457 & 10.06 & 11.83 \\
\hline
\end{tabular}

finding corroborates some scholars' argument, which stated that even under the condition of no revision opportunity, WCF can be effective (Shintani \& Ellis, 2015) and learners can succeed in noticing corrections (Ellis, 2009) as long as learners are required to notice and process the received corrections (Shintani \& Ellis, 2015). Further, the finding is in line with the statement that drawing learner attention can be achieved by asking them to take time to look over the received feedback and carefully examine their errors (Ellis, 2009; Polio, 2012).

Unfortunately, in this study, the learners' understanding and interpretation of the received treatments were not investigated; therefore the discussion about the superiority of attention requirement $(\mathrm{DCF} /+\mathrm{S})$ over the revision requirement $(\mathrm{DCF} /+\mathrm{R})$ is confined to some speculations, albeit with regard to some scholarly views.

It has already been stated that even when students are able to accurately revise a text based on the provided feedback, "it is not guaranteed that they have understood the feedback" (Simard, Guénette, \& Bergeron, 2015, p. 235). As Guénette (2012, p. 123) stated, "Noticing an error is not the same as being able to correct it." Noticing and understanding are two levels of awareness. Nonetheless, noticing is the most basic sense of "being aware of something" (Schmidt, 1993, p. 211) while understanding is the higher level of awareness than simply noticing (Schmidt, 1993). Although learners' noticing is necessary for second-language (L2) development (Schmidt, 1990, 2001), in the higher level of awareness (i.e. understanding), learners are able to recognize patterns or rules (Schmidt, 1995) and make generalizations across instances (Schmidt, 2010, as cited in Simard et al., 2015). At the level of understanding, leaners are able to "analyze, compare, and test hypotheses, [which] leads to deeper learning marked by restructuring and system learning. On the other hand, awareness at the level of noticing leads to mere intake of linguistic information" (Leow, 2006, p. 127).

In short, revision could help learners notice their errors, yet noticing alone, without understanding "does not imply that learners will be able to modify their language system" based on the provided CF (Simard et al., 2015, p. 236). Therefore, it is likely that the participating learners in the revision requirement group (DCF/+R) did not understand some of the received feedback and only looked at direct corrections and copied them onto a new piece of writing, as explained by Polio (2012). However, the participants in the attention requirement group $(\mathrm{DCF} / \mathrm{S})$ needed to carefully study the received feedback, so understanding could have taken place.

As the concluding remarks, some points need to be mentioned. First, as it was already mentioned, this study did not investigate the learners' actual engagement in, understanding, and interpretations of the WCF. Therefore, these issues had better be explored in future studies via think-aloud or interviews. Further, the investigated issue in the present study is recommended to be explored considering the important factor of individual differences because as (Hanaoka \& Izumi, 2012, p. 333) stated, there are several "learner internal factors such as learners' aptitude, developmental readiness, and various affective factors", which can promote or inhibit learners' noticing.

\section{REFERENCES}

Bitchener, J. (2008). Evidence in support of written corrective feedback. Journal of Second Language Writing, 17(2), 102-118. https://dx.doi.org/10.1016/j.jslw.2007.11.004

Bitchener, J., \& Ferris, D. R. (2012). Written corrective feedback in second language acquisition and writing. New York, NY: Routledge. 
Bruton, A. (2009). Improving accuracy is not the only reason for writing, and even if it were. System, 37(4), 600-613. https://dx.doi.org/10.1016/j.system.2009.09.005

Chandler, J. (2003). The efficacy of various kinds of error feedback for improvement in the accuracy and fluency of L2 student writing. Journal of Second Language Writing, 12(3), 267-296. https://dx.doi.org/10.1016/ S1060-3743(03)00038-9

Ellis, R. (2009). A typology of written corrective feedback types. English Language Teaching, 63(2), 97-107. https://dx.doi.org/10.1093/elt/ccn023

Ellis, R. (2010). EPILOGUE: A framework for investigating oral and written corrective feedback. Studies in Second Language Acquisition, 32(2), 335-349. https://dx.doi. org/10.1017/S0272263109990544

Ellis, R., Sheen, Y., Murakami, M., \& Takashima, H. (2008). The effects of focused and unfocused written corrective feedback in an English as a foreign language context System, 36(3), 353-371. https://dx.doi.org/10.1016/j. system.2008.02.001

Elwood, J. A., \& Bode, J. (2014). Student preferences visà-vis teacher feedback in university EFL writing classes in Japan. System, 42(1), 333-343. https://dx.doi. org/10.1016/j.system.2013.12.023

Ferris, D. R. (2004). The "grammar correction" debate in L2 writing: Where are we, and where do we go from here? (and what do we do in the meantime.?). Journal of Response to Writing, 13(1), 49-62. https://dx.doi. org/10.1016/j.jslw.2004.04.005

Ferris, D. R. (2006). Does error feedback help student writers? New evidence on the short- and long-term effects of written error correction. In K. Hyland \& F. Hyland (Ed.), Feedback in second language writing: Contexts and issues (pp. 81-104). Cambridge, UK: Cambridge University Press.

Ferris, D. R. (2010). Second language writing research and written corrective feedback in SLA: Intersections and practical applications. Studies in Second Language Acquisition, 32(2), 181-201. https://dx.doi.org/10.1017/ S0272263109990490

Ferris, D. R. (2014). Responding to student writing: Teachers' philosophies and practices. Assessing Writing, 19, 6-23. https://dx.doi.org/10.1016/j.asw.2013.09.004

Field, A. (2013). Discovering statistics using SPSS ( $4^{\text {th }}$ ed.). London: Sage.

Frear, D. (2012). The effect of written corrective feedback and revision on intermediate Chinese learners' acquisition of English. (Doctoral dissertation). New Zealand: The University of Auckland. Retrieved from https://researchspace.auckland.ac.nz/bitstream/handle/2292/20005/whole.pdf?sequence $=2$

Geranpayeh, A. (2003). A quick review of the English quick placement test. Extract from Research Notes, 12, 8-10. Retrieved from http://www.lingue.uniss.it/documenti/ lingue/what_is_the_QPT.pdf

Guénette, D. (2007). Is feedback pedagogically correct? Research design issues in studies of feedback on writing. Journal of Second Language Writing, 16(1), 40-53. https://dx.doi.org/10.1016/j.jslw.2007.01.001
Guénette, D. (2012). The pedagogy of error correction: Surviving the written corrective feedback challenge. TESL CANADA JOURNAL/REVUE TESL DU CANA$D A, 30(1), 117-126$. https://dx.doi.org/10.18806/tesl. v30i1.1129

Han, Y., \& Hyland, F. (2015). Exploring learner engagement with written corrective feedback in a Chinese tertiary EFL classroom. Journal of Second Language Writing, 30,31-44. https://dx.doi.org/10.1016/j.jslw.2015.08.002

Hanaoka, O., \& Izumi, S. (2012). Noticing and uptake: Addressing pre-articulated covert problems in L2 writing. Journal of Second Language Writing, 21(4), 332-347. https://doi.org/10.1016/j.jslw.2012.09.008

Hyland, F. (2003). Focusing on form: Student engagement with teacher feedback. System, 31(2), 217-230. https:// dx.doi.org/10.1016/S0346-251X(03)00021-6

Hyland, K. (2013). Student perceptions of hidden messages in teacher written feedback. Studies in Educational Evaluation, 39(3), 180-187. https://dx.doi.org/10.1016/j.stueduc. 2013.06 .003

Hyland, K., \& Hyland, F. (2006). Feedback on second language students' writing. Language Teaching, 39(2), 83. https://dx.doi.org/10.1017/S0261444806003399

Lalande, J. F. (1982). Reducing composition errors: An experiment. The Modern Language Journal, 66(2), 140-149. https://dx.doi.org/10.1111/j.1540-4781.1982. tb06973.x

Larson-Hall, J. (2010). A guide to doing statistics in second language research using SPSS. New York, NY: Routledge.

Lee, I. (2004). Error correction in L2 secondary writing classrooms: The case of Hong Kong. Journal of Second Language Writing, 13(4), 285-312. https://dx.doi. org/10.1016/j.jslw.2004.08.001

Lee, I. (2005). Error correction in the L2 writing classroom: What do students think? TESL Canada Journal, 22(2), 1-16. https://dx.doi.org/10.18806/tesl.v22i2.84

Lee, I. (2008). Understanding teachers' written feedback practices in Hong Kong secondary classrooms. Journal of Second Language Writing, 17(2), 69-85. https://dx. doi.org/10.1016/j.jslw.2007.10.001

Leki, I. (1991). The preferences of ESL students for error correction in college-level writing classes. Foreign Language Annals, 24(3), 203-218. https://dx.doi. org/10.1111/j.1944-9720.1991.tb00464.x

Leow, R. P. (2006). The role of awareness in L2 development: Theory, research, and pedagogy. Indonesian Journal of English Language Teaching, 2(2), 125-139. Retrieved from ojs.atmajaya.ac.id/index.php/ijelt/article/ view/119/78

Liu, Q., \& Brown, D. (2015). Methodological synthesis of research on the effectiveness of corrective feedback in L2 writing. Journal of Second Language Writing, 30, 66-81. https://dx.doi.org/10.1016/j.jslw.2015.08.011

Mackey, A., \& Gass, S. M. (2005). Second language research: Methodology and design. Mahwah, New Jersey: Lawrence Erlbaum Associates, Inc.

Mawlawi Diab, N. (2015). Effectiveness of written corrective feedback: Does type of error and type of correction 
matter? Assessing Writing, 24, 16-34. https://dx.doi org/10.1016/j.asw.2015.02.001

Oladejo, J. A. (1993). Error correction in ESL: Learners' preferences. TESL Canada Journal, 10(2), 71-89. https://dx.doi.org/10.18806/tesl.v10i2.619

Pallant, J. (2013). SPSS survival manual: A step by step guide to data analysis using IBM SPSS ( $5^{\text {th }}$ ed.). Berkshire, England: Open University Press.

Phakiti, A. (2010). Analysing quantitative data. In B. Paltridge \& A. Phakiti (Eds.), Continuum companion to research methods in applied linguistics (pp. 39-49). New York, NY: Continuum Companions.

Polio, C. (2012). The relevance of second language acquisition theory to the written error correction debate. Journal of Second Language Writing, 21(4), 375-389. https://dx.doi.org/10.1016/j.jslw.2012.09.004

Sachs, R., \& Polio, C. (2007). Learners' uses of two types of written feedback on a L2 writing revision task. Studies in Second Language Acquisition, 29(1), 67-100. https:// dx.doi.org/10.10170S0272263107070039

Saslow, J., \& Ascher, A. (2012). Summit 2: English for today's world ( $2^{\text {nd }}$ ed.). Pearson Education.

Schmidt, R. (1993). Awareness and second language acquisition. Annual Review of Applied Linguistics, 13, 206226. https://dx.doi.org/10.1017/S0267190500002476

Schmidt, R. W. (1990). The role of consciousness in second language learning. Applied Linguistics, 11(2), 129-158. https://dx.doi.org/10.1093/applin/11.2.129

Schmidt, R. W. (1995). Consciousness and foreign language learning: A tutorial on the role of attention and awareness in learning. In R. W. Schmidt (Ed.), Attention and awareness in foreign language learning and teaching (pp. 1-63). Honolulu, HI: University of Honolulu.

Schmidt, R. W. (2001). Attention. In P. Robinson (Ed.), Cognition and second language instruction (pp. 3-32). Cambridge, UK: Cambridge University Press.

Sheen, Y. (2007). The effect of focused written corrective feedback and language aptitude on ESL learners' acquisition of articles. TESOL Quarterly, 41(2), 255-283. https://dx.doi.org/10.1002/j.1545-7249.2007.tb00059.x

Sheppard, K. (1992). Two feedback types: Do they make a difference? RELC Journal, 23(1), 285-304. https://dx. doi.org/10.1177/003368829202300107

Shintani, N., \& Ellis, R. (2013). The comparative effect of direct written corrective feedback and metalinguistic explanation on learners' explicit and implicit knowledge of the English indefinite article. Journal of Second Language Writing, 22(3), 286-306. https://dx.doi. org/10.1016/j.jslw.2013.03.011

Shintani, N., \& Ellis, R. (2015). Does language analytical ability mediate the effect of written feedback on grammatical accuracy in second language writing? System, 49, 110-119. http://dx.doi.org/10.1016/j.system.2015.01.006
Shintani, N., Ellis, R., \& Suzuki, W. (2014). Effects of written feedback and revision on learners' accuracy in using two English grammatical structures. Language Learning, 64(1), 103-131. https://dx.doi.org/10.1111/ lang.12029

Simard, D., Guénette, D., \& Bergeron, A. (2015). L2 learners' interpretation and understanding of written corrective feedback: Insights from their metalinguistic reflections. Language Awareness, 24(3), 233-254. https://dx.doi.org $/ 10.1080 / 09658416.2015 .1076432$

Stefanou, C., \& Révész, A. (2015). Direct written corrective feedback, learner differences, and the acquisition of second language article use for generic and specific plural reference. Modern Language Journal, 99(2), 263-282. https://dx.doi.org/10.1111/modl.12212

Storch, N. (2010). Critical feedback on written corrective feedback research. International Journal of English Studies, 10(2), 29-46. Retrieved from https://dialnet. unirioja.es/descarga/articulo/3424315.pdf

Storch, N., \& Wigglesworth, G. (2010). Learners' processing, uptake, and retention of corrective feedback on writing: Case studies. Studies in Second Language Acquisition, 32, 303-334. https://dx.doi.org/10.1017/ S0272263109990532

Suzuki, W. (2012). Written languaging, direct correction, and second language writing revision. Language Learning, 62(4), 1110-1133. https://dx.doi.org/10.1111/j.14679922.2012.00720.x

Swain, M. (1985). Communicative competence: Some roles of comprehensible input and comprehensible output in its development. In S. M. Gass \& C. G. Madden (Eds.), Input in second language acquisition (pp. 64-81). Cambridge, UK: Cambridge University Press.

Swain, M. (1995). Three functions of output in second language learning. In G. Gook \& B. Seidlhofer (Eds.), Principle and practice in applied linguistics (pp. 125-144). Oxford: Oxford University Press.

Truscott, J., \& Hsu, A. Y. (2008). Error correction, revision, and learning. Journal of Second Language Writing, 17(4), 292-305. https://dx.doi.org/10.1016/j. jslw.2008.05.003

Van Beuningen, C. G. (2010). Corrective feedback in L2 writing: Theoretical perspectives, empirical insights, and future directions. International Journal of English Studies, 10(2), 1-27. Retrieved from http://revistas. um.es/ijes/article/view/119171

Van Beuningen, C. G., De Jong, N. H., \& Kuiken, F. (2012). Evidence on the effectiveness of comprehensive error correction in second language writing. Language Learning, 62(1), 1-41. https://dx.doi.org/10.1111/j.14679922.2011.00674.X

Williams, J. (2012). The potential role(s) of writing in second language development. Journal of Second Language Writing, 21(4), 321-331. https://dx.doi.org/10.1016/j. jslw.2012.09.007 